\title{
Михуйин А. ЖИВКОВИЋ
}

Институт за српску културу - Приштина, Аепосавић

\author{
ПОСЕТА ЈУГОСАОВЕНСКОГ \\ ПРЕАСЕАНИКА ЈОСИПА БРОЗА ЕГИПТУ \\ $(28.12 .1955-06.01 .1956)^{* *}$
}

\begin{abstract}
$A \bar{u} c \bar{u} p a \kappa \bar{u}:$ РаА анализира резултате које је, пре свега на политичком плану, постигла југословенска Аипломатска Аелегација преАвођена Јосипом Брозом за време посете Египту крајем 1955. и почетком 1956. године, а у светлу очекивања међународне зајеАнице и водећих светских медија. Посета је посматрана и из угла југословенске спољнополитичке платформе несврстаности која је настајала тих година. РаА је писан на основу изворне документације настале радом југословенских савезних органа у том периоду, која се чува у Архиву Југоскавије у Београду, те периодике и одабране научне митературе.

Кьучне речи: Југославија, Египат, Јосип Броз, Гамал АбАем Насер, посета, ЗапаА, Вемика Британија, Етиопија, Аелегација, преАсеАник.
\end{abstract}

Путовање југословенске Аелегације у Египат уследимо је одмах после боравка у Етиопији крајем децембра 1955. године. Радимо се о захтевној и Аугој дипломатској кампањи. Током десетодневног боравка у земьи на Нику Јосип Броз је неколико пута званично и незванично разговарао са Насером (Nasser). Ту прилику је искористио Аа му представи спољнополитичку платформу мироьубиве коегзистенције коју је градила Југославија. Имао је намеру и Аа, према жељама Запада, покуша Аа сугерише Насеру мирно решавање проблема са Израелом на Блиском истоку. Египатски преАсеАник је, међутим, одбио овај преАлог. Стога југословенска Аипмоматија Ааје јаку поАршку Египту и, супротстављајући се западним интересима који су угрожавали ову афричку земьу, трасира сопствени пут на блоковски подењеној међународној сцени.

* научни сарадник, mzivkovickv@gmail.com

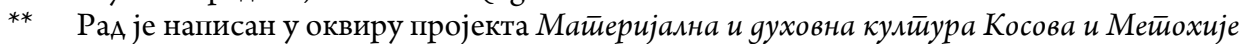
(ев. број 178028), који је одобрило и финансира Министарство просвете, науке и технолошког развоја Републике Србије. 
Посета Јосипа Броза Египту привукла је више пажње оА првог Аела његове афричке турнеје. Аок је „Галеб“ путовао као Суецу, светска јавност је прогнозирала резултате разговора између југословенског преАсеАника Јосипа Броза и египатског лидера Гамала АбАела Насера. ОА првог се очекива$\Lambda$ Аа утиче на смиривање вишедеценијског сукоба између Арапа и Јевреја. Амерички државни секретар Џон Фостер Aалс (Dulles) и британски премијер Ентони ИАН (Eden) су у оАвојеним, али блиским терминима, сугерисами Југославији Аа се, уколико је могуће, прихвати посредничке умоге у овом спору. Југословенска дипломатија је Аала одређена обећања, која ипак својим карактером нису обавезивала Броза да се прихвати овог задатка у оном облику у којем је то желео ЗапаА. Продором Совјета на Блиски исток и у остатак Азије, оличеним у продаји чехословачког оружја Египту и посети Хрушчова (Khrushchev) и Букгањина (Bulganin) Индији, Пакистану и Авганистану у децембру 1955 . године, ${ }^{1}$ Броз је требамо и Аа оАвоји Египат оА растућег утицаја СССР. ${ }^{2}$

У Аецембру 1955. године сукоби на Блиском истоку су ескалирали. Аванаестог Аецембра израелска војска је напала Сирију у предеку Тиберијског језера. ${ }^{3}$ Насер је, као мидер арапског света, реаговао мобилизацијом египатске војске. Неколико Аана касније, 19. Аецембра, он је у јавност изашао са порукама о скоријем сукобу („Биће ми Араго каАа се египатска и сиријска армија буду састале у Израелу на рушевинама израелског подмукцог народа“). ${ }^{4}$ Израелски премијер АавиА Бен Гурион (Ben-Gurion) узвратио је истом мером поручивши Насеру аа ће се његова земьа „борити и победити уз цену свих жртава“. 5 Тензију је појачама експлозија бомбе испреА сеАишта Арапске миге у Каиру. ${ }^{6}$ Истовремено су избили сукоби против нове

1 Крањ Саудијске Арабије СуаА је управо у време боравка Хрушчова и Булгањина на југоистоку Азије отишао у посету Индији. ЗапаА је у овоме видео и Насеров утицај. Архив Југоскавије (АЈ), фонА 112, ТАНЈУГ, кут(ија) 179, Црвени билтен за 05. 12. 1955. године.

2 Почетком децембра у Египат је стигло $22.000 \mathrm{t}$ рафинираног петролеја из СССР. Исто; Пошто је Израел био темељ западног утицаја на Блиском истоку, онемогућавајући ујеАињење и самостални развој арапских Аржава, што је, опет, био главни преАуслов за политичку и економску доминацију западних сила и пре свега, неометану експиотацију нафте, он се морао одржати по сваку цену. Међутим, са продором совјетског наоружања у регион, независност Израела више није могла да се одржава путем неравномерне расподеме наоружања земљама Блиског истока, коју су до тада спроводиме западне симе. Аужи оружани сукуб који би Аестабилизовао Блиски исток и прекинуо снабдевање западних привреда нафтом, постао је реална опција. Исто, кут. 181, Црвени билтен за 27. 12. 1955. године.

3 Исто, кут. 180, Црвени билтен за 12. 12. 1955. године.

4 Исто.

5 Исто, кут. 181, Црвени билтен за 27. 12. 1955. године.

6 Исто, кут. 179, Црвени билтен за 07. 12. 1955. године. 
пробританске вмаде у Јордану. Сукоб између војске и народа имао је крвав епимог. ${ }^{7}$ И у Аибану је такође дошло до протеста против пробританске владе. ${ }^{8}$ У исто време Судан је прогласио независност оА Велике Британије. У таквој атмосфери југословенске Аипломате су стигле у Египат.

Брозова посета Египту уговорена је још почетком 1955, када се југословенски председник срео са Насером на Суецу. Они су тада одредили да hе званична посета бити у децембру исте године. Пошто се, међутим, путовање у Египат надовезивало на посету Етиопији, приликом чије организације је бимо доста проблема, посета Египту је померена за 14 дана, односноч за крај Аецембра и почетак јануара 1956. године. Египатска вмада је покушала Аа путем штампе притисне Југославију Аа се посета спроведе половином послеАњег месеца у 1955. години. ${ }^{9}$ Овакав потез се може објаснити потребом Каира Аа Броз Аође у Египат, независно оА тога Аа ки ће отићи у Етиопију. Ако би он Аошао само у посету Египту, то би Каиру донело престиж у односу на ААис Абебу, са којом су односи били затегнути. Боравак југословенске Аелегације у Египту трајао је на крају од 28. Аецембра 1955. Ао 6. јануара 1956. године.

Припреме за пут у Египат су вршене истовремено са онима за посету Етиопији, па је све Ао ситница бимо преАвиђено. То је био задатак југословенског амбасадора у Египту Марка Никезића и Аржавног секретаријата за иностране послове (АСИП). Бимо је преАвиђено која се одела и униформе носе, ${ }^{10}$ шта ће се оА пића и хране понети, која ће музика свирати за дочек ${ }^{11}$ Нове године и где ће се одржати „прослава“" ${ }^{12}$ које ће се заставице ности на аутомобилима, ${ }^{13}$ каква је епидемиолошка ситуација у Египту и против чега би требало вакцинисати чманове делегације, ${ }^{14}$ какав је квалитет пијаће воАе ${ }^{15}$ итА. Прецизност је некаАа прелазила у ситничавост. ${ }^{16}$

Непосредно преА Аолазак југословенске мисије у Египат, агент Аржавне безбедности (АБ) Ђуро Станковић је обишао сва места у којима је она требало Аа борави и одседне. Обишао је палату „Кубе“ у Каиру, Брозову привремену резиденцију, Александрију, Һуксор, Карнак и Аолину краьева, Бараж на Нилу, Асуан итА. О свом путу поднео је извештај министру

\footnotetext{
7 Исто, кут. 181, Црвени билтен за 24. 12. 1955. године.

8 Исто, кут. 180, Црвени билтен за 12. 12. 1955. године.

9 АЈ, фонА 837, Кабинет преАсеАника Републике (КПР), I-2/5 -2, 4.

10 AJ, 837, I - 2/5 - 2, 14.

11 Исто, 50.

12 Исто, 60.

13 Исто, 32.

14 Исто, 35-36.

15 Исто, 35.

16 Из југословенске амбасаде су стизале опомене Аа воће при јелу „треба прати и ьуштити“, Аа се приликом јема сирових паприка, парадајза и краставаца они обавезно морају опрати „четкицом и сапуном“, Аа се јагоде не смеју јести због прљавштине, а Аа се млеко пије само кувано. Исто.
} 
унутрашњих послова Светилсаву Стефановићу 24. Аецембра 1955. године. ${ }^{17}$ И египатски органи су посветили вемику пажњу безбеАности Југословена. ${ }^{18}$ Посебно су се ангажовали око Брозовог боравка у Ауксору, где је по плану требало Аа се прославе новогодишњи празници. И пореА тога, Броз је морао Аа прихвати мош смештај за себе и своју свиту с обзиром на то Аа је туристичка сезона у Египту бима у пуном јеку. ${ }^{19}$

Бимо је неопходно организовати и накнаАни домазак преАсеАникове супруге Јованке Броз, будући Аа она није путовама у Етиопију. Занимьиво је Аа она све до 22. Аецембра није знала Аа иде у Египат. Тада се обратима Јожеу Бримеју јеАном Аепешом, тражећи Аа он организује пут, али Аа то „учини сам и не узнемирава“ њеног мужа. ${ }^{20}$ Јованка се тако први пут приАружила свом супругу током јеАне оА његових посете страној земьи и оА тала ће му бити чест сапутник. ${ }^{21}$

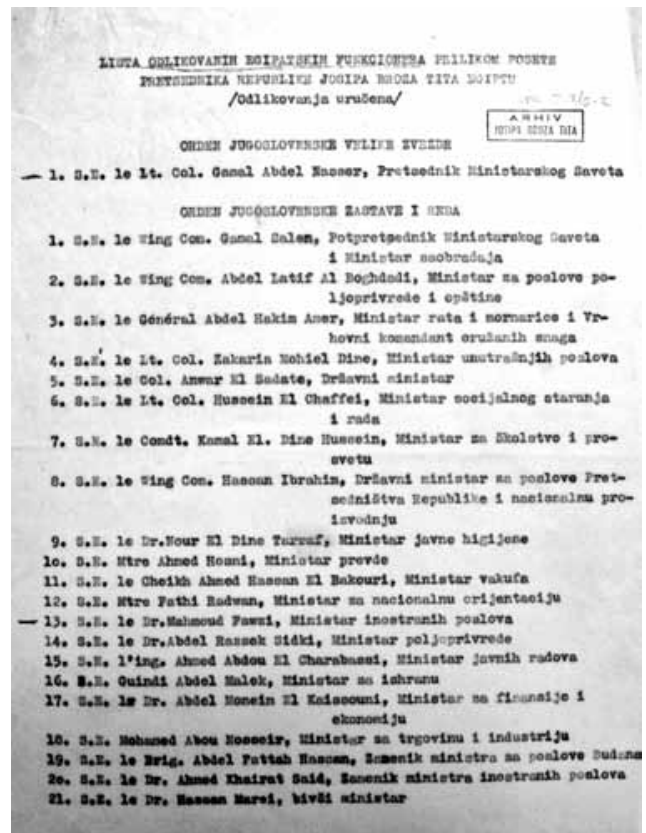

Слика 1. Сйисак одмиковања која су gобияи еїийайски званичници (Архив Jуїославије, фонg 837, КПР)

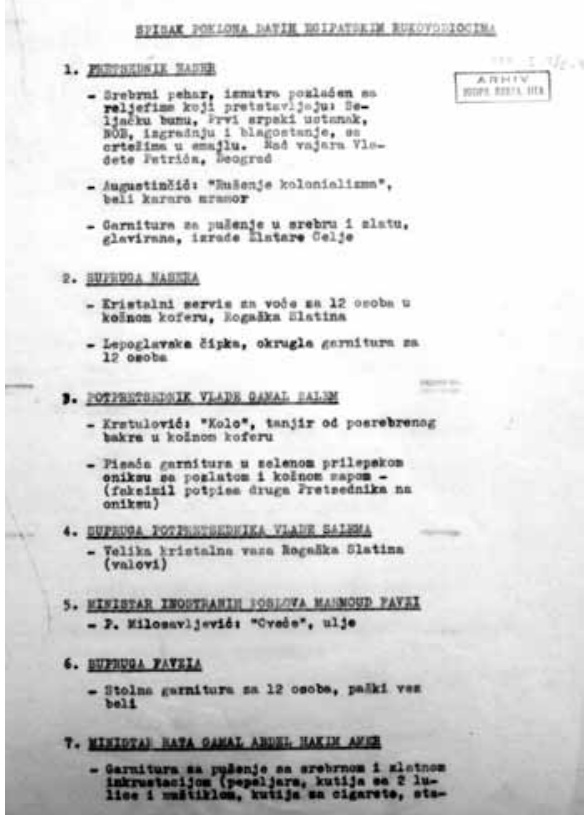

Слика 2. сииисак йоклона које су gобили највиши еїийайски званичници (Архив Jyīocıaвије, фонg 837, КПР)

17 Исто, 41.

18 Југословенски органи безбедности су преАали мисту са 32 емигранта за хапшење и другу на којој је бимо 17 мица које је требамо посматрати. Египћани су брзо оАрадили свој Аео посла. Исто, 29.

19 Исто, 33-34.

20 Исто, 87.

21 АJ, 112-181, Црвени билтен за 27. 12. 1955. године. 
Што се тиче одликовања, египатским званичницима је додењено 147 знамења, Аок су чманови југословенског Аипмоматског тима добими $78 .{ }^{22} \mathrm{Ky-}$ риозитет је била чињеница Аа је пуковник Насер сваки орден мично додемио, што опет сведочи о углеАу који су југословенска Аелегација и пре свега њен шеф Јосип Броз уживали у овој афричкој земьи. ${ }^{23}$

Многобројним египатским званичницима донети су покмони из Југоскавије. ${ }^{24}$ Насер је добио сребрни пехар, изнутра позмаћен, са рељефима који су преАстављали сељачку буну, Први српски устанак, НОБ, изграАњу и благостање са цртежима у емајку. Примио је и скулптуру „Рушење колонијамизма“" вајара Антуна Аугустинчића. ${ }^{25}$ Видимо Аа су југословенски комунисти придавали велику пажњу одабиру поклона за стране Аржавнике, који су увек били више оА обичног Аара. Египатски преАсеАник је узвратио Брозу тако што му је поклонио античку вазу из периода Новог царства, коју је узео из Националног музеја у Каиру. ${ }^{26}$ Аруги египатски званичници добијали су разне кристалне вазе, комплете, чиније, пиксле, скулптуре од мермера, бронзе и дрвета, предмете и одећу народне радиности, зматне и сребрне табакере, сатове марке „Шафхаузен“ и „Омега“, слику маршала Тита у војној униформи са аутограмом у кожном повезу итА. ${ }^{27}$

Југословенски церемонијални броА „Галеб“ пристао је у Суец 28. Аецембра 1955. године. На свечаном дочеку окупио се велики број египатских званичника предвођених министром рата Мухамедом Амером (Amer). После краћег путовања возом југословенска делегација је стигла у Каиро, гАе јој је приређен дочек. На железничкој станици чекао ју је Насер са најближим сарадницима (онима који нису отишли у Суец). Том приликом Јосип Броз је оАржао краћи говор у центру Каира, током којег је, између осталог, поручио присутнима: „Истоветност нашег глеАања на многе проблеме испоьияа се још при нашем ранијем сусрету и ја сам дубоко уверен Аа ће преАстојећи разговори са преАсеАником Насером Аати још плоАније резултате и Аа ће још више ојачати пријатељске односе и сарадњу између наших земаља“. ${ }^{28}$

ПреАсеАник Југославије је АоАао Аа су зајеАничка револуционарна искуства Ава народа темељ билатералне сарадње. После смештаја гостију у бившу резиденцију краља Фарука - палату Кубех, 28. децембра увече оАржан је

22 AJ, 837, I - 2/5 - 2, 275.

23 Исто, 264.

24 Поклоне је Аобила 71 особа, Аок је укупан број разних дарова износио 94. Једног Египћанина, који се огромном брзином попео и спустио низ Кеопсову пирамиду, Броз је мично наградио зматном табакером. Исто, 213-218.

25 Исто, 213.

26 Исто, 225.

27 Исто, 213-218.

28 Исто, 616-617. 
свечани банкет на којем су Аржани говори добродошлице. Притом су Египћани упозорили Аа Брозово обраћање буде што краће, јер је преАсеАник ИнАонезије Сукарно (Sukarno) говорио чак 40 минута па су се сва јела охлади$\Lambda$ a, а пријем пропао. ${ }^{29}$ Банкету су, пореА осталих, присуствовали ватикански нунције и дипломатски представници Формозе (Тајвана) и Франкове Шпаније, иако Југославија није гајима пријатеьске односе са овим земьама. ${ }^{30} \mathrm{Ha}$ сер је у својој зАравици позАравио борбу југословенског народа и њеног миАера у Аругом светском рату и притом се заложио за стварање трајног мира у свету, уз поштовање права малих народа и политике немешања у њихове унутрашње послове оА стране векиких сила. ${ }^{31}$

Југословенски мидер је на то одговорио „Аа је египатска ревокуција јасно показала Аа и народи овог пространог континента не желе Аа буду третирани као објекти светске политике, већ желе и способни су Аа Аелују као њени субјекти, тј. као независни и равноправни чланови међунарАне зајеАнице“. ${ }^{32}$ У наставку зАравице Броз је, као и његов колега, истакао потребу поштовања принципа активне мироьубиве коегзистенције, односно помитике несврстаности.

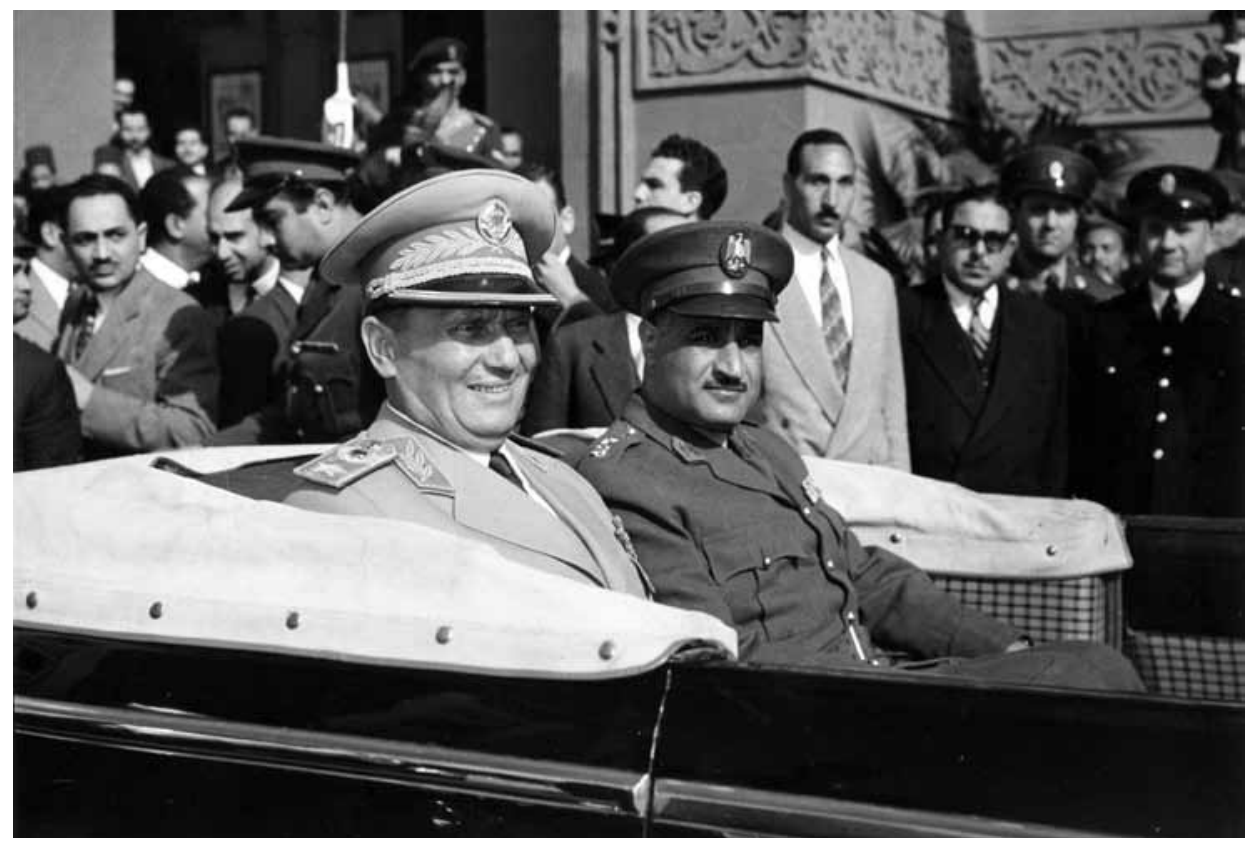

Слика 3. Јосий Броз и Гамал Абgел Насер ирриликом ироласка кроз Каиро 28. gечембра 1955. іолине (Музеј Jуїославије, К-52-32)

29 Исто, 20.

30 Исто, 13-15.

31 Исто, 624.

32 Исто, 638. 
После званичних разговора између Броза и Насера 29. Аецембра, југословенски преАсеАник је наредног Аана посетио Војну академију у Каиру и Музеј исламске уметности. ${ }^{33}$ Увече је организован пријем за Насера и његове најближе сараднике у палати Кубех. Потом је југословенска Аелегација кренула ка $\Lambda$ усору, где је стигла 31. децембра ујутру. ОАмах се приступимо организацији поменуте новогодишње прославе. Аочек је провеАен у пријатној атмосфери и потрајао је Ао раних јутарњих часова. Први и Аруги јануар потрошени су на обилазак храмова у Карнаку и $\Lambda$ усору, односно посету Аолини краљева и месту на коме је планирана изградња бране на Нилу.

Трећег јануара Броз се са пратњом вратио у Каиро. Тамо је обишао Национални музеј Египта, Аок је наредног Аана био у посети фабрици оружја и официрском клубу. ${ }^{34}$ Поподне 4. јануара Броз и Насер су присуствовали кошаркашкој утакмици између КК „Црвена Звезаа“ и КК „Gezira Sporting Club““ ${ }^{35}$ Разговори између Авојице Аржавника одржани су 5. јануара у Каиру. Југословенски милер је после тога у пратњи Насера отишао у посету Александрији. После тога, 6. јануара увече, југословенска Аелегација се укрцала на „Галеб“ и испиовияа ка Балкану. ${ }^{36}$

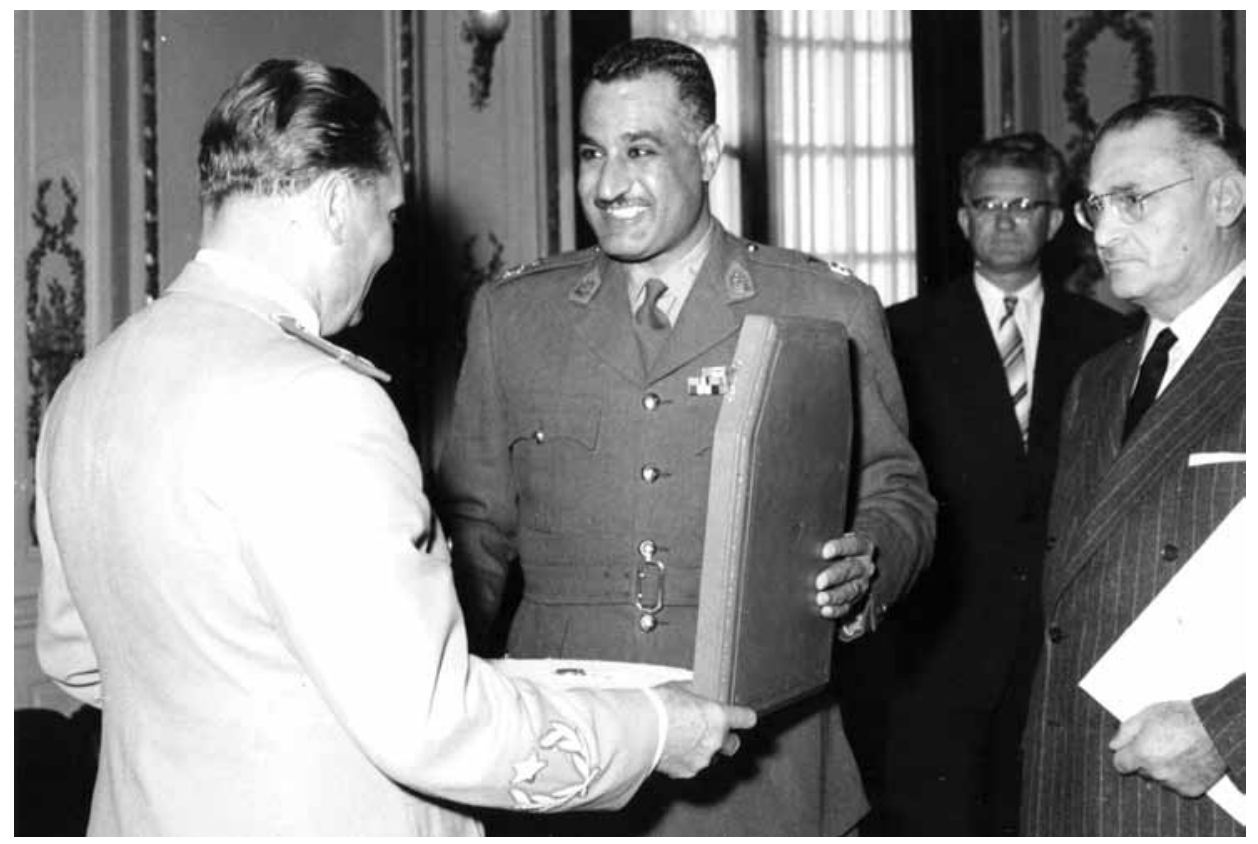

Слика 4. Примойреgаја йоклона тиоком свечаної банкейа

(Музеј Југославије, К-52-36)

33 Исто, 63.

34 Исто, 64.

35 АJ, 112-179, Црвени билтен за 04. 12. 1955. године.

36 AJ, 837, I-2/5-2, 64. 


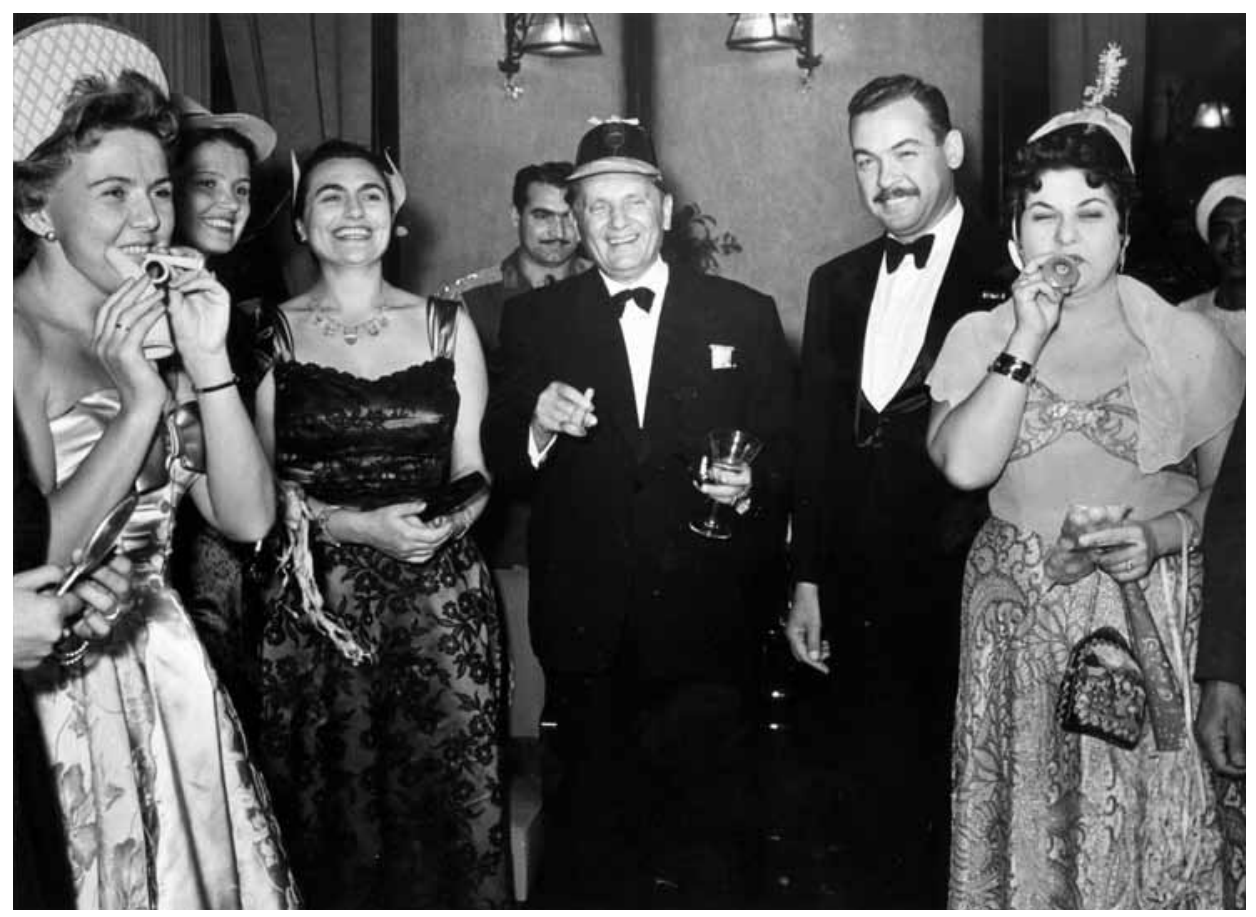

Слика 5. Новоіоочињь йрослава у Ауксору 1956. їодине (Музеј Jуїославије)

Западне симе, у првом реду Велика Британија и САА, полагале су наду у разговоре Броз-Насер. Њихова очекивања се могу пратити кроз страну штампу. Име Јосипа Броза је медбело у етру светског интересовања више оА месец Аана. Прве најаве његовог могућег посредовања између Египта и Израема јавиле су се почетком децембра, Аа би постале све учесталије оА половине месеца. Такве вести доносе британска, америчка, француска, италијанска, немачка и грчка штампа. Требало би нагласити Аа су текстови у Аецембарској запанној штампи углавном пристрасни, јер су на југословенско блискоисточно присуство глеАали из перспективе интереса Велике Британије и САА. Притом су реалне анализе југословенског спомнополитичког опредељења биме ретке.

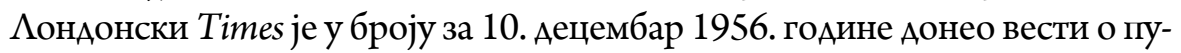
товању југословенског преАсеАника у Египат, пишући Аа је стабилност Блиског истока битна за југословенску дипломатију и да ће стога, „стање у односима између Арапа и Израела нужно заузимати истакнуто место у овим југословенско-египатским односима“. ${ }^{37}$ Reuters је непосредно преА Брозов долазак у Каиро објавио вест Аа је југословенски преАсеАник индиректним путем обећао израелској влади да ће посредовати мирном решењу блискоисточне кризе. ${ }^{38}$

37 АJ, 112-180, Црвени билтен за 15. 12. 1955. године.

38 AJ, 837, I- 6/без броја, Реферат о арапско-израелском спору и оАносима Египта са Вемиком Британијом и САА. 


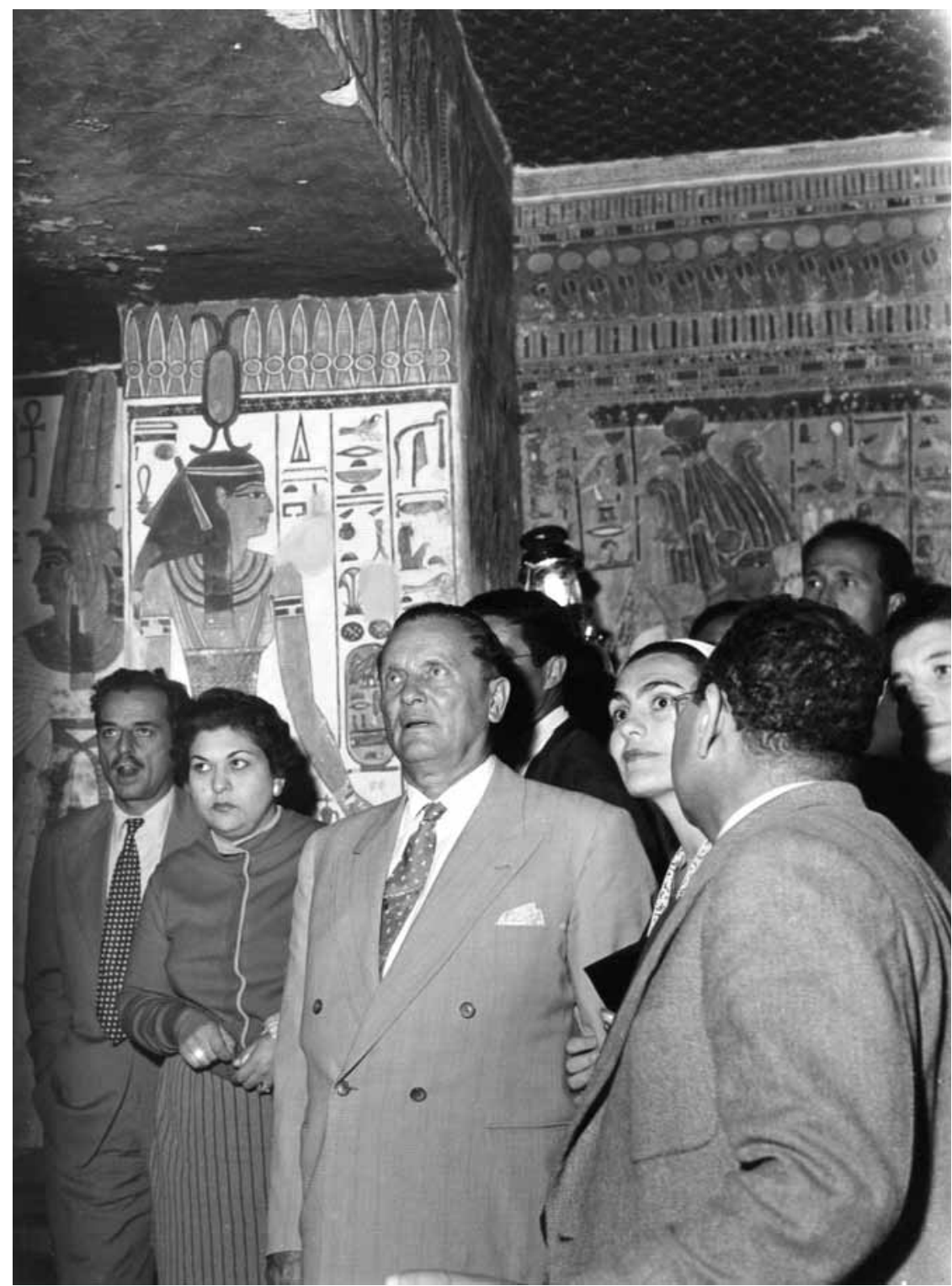

Слика 6. Јосий и Јованка Броз и Констианитин Поиовић йоком обиласка Туйанкамонове іробнице 1. јануара 1956. іолине (Музеј Jуїославије)

Аемократски Torchmen је 22. Аецембра поставио питање: може ми Броз Аа „оАигра улогу посредника у вези арапско-израелског сукоба и Аа у том смиску учини серију покушаја?"399 Позивајући се на југословенски извор из Вашингтона, New Herald Tribune је писао да ће Југосмовени „убеђивати египатског премијера Насера Аа се реалистички односи према палестинској кризи и Аа тежи

AJ, 112-181, Црвени билтен за 22. 12. 1955. године. 
миру са Израемом “. ${ }^{40}$ New York Times је 29. децембра, са истим преудбеђењем, на страницама Аиста изнео став Аа „влада мишьење Аа ће Авојица мидера Аискутовати о затегнутости и сукобима између Израела и арапских земаља“. 41

Бимо је покушаја Аа се кроз медије Брозова посета Египту прикаже блискоисточној јавности као западна мировна интервенција, а југословенски мидер као инструмент њене политике. НепосреАно преА почетак посете Reuters је обнародовао Аа је југословенски председник преко Светозара Вукмановића, који је нешто раније боравио у Израеку, понудио премијеру Бен Гуриону аа посредује у спору са Арапима и да су Израелци ту пунуду прихватили. ${ }^{42}$ Истовремено је америчка обавештајна служба дотурила јеАан Аокумент Египатској амбасади у Вашингтону, који описује Броза као марионету светског ционизма, а његов пут у Египат објашњава искьучиво преношењем нових мировних иницијатива за споразум између Египта и Израела (Petrović 2007: 116-117). Египатска вмада је, међутим, одбацима обе информације оцењујући их као акт западне пропаганде уперен против југословенско-египатског пријатеьства.

Западна штампа је шпекулисала и око Аругих циљева југословенске дипломатије у Египту. Појавьују се вести о могућој Брозовој посети Израеку посме боравка у Етиопији и Египту. ${ }^{43}$ Franc-Tireur говори на ту тему у броју за 29. Аецембар Аодајући „да за путника који се враћа из Етиопије Јерусалим није Аалеко, већ преАставља само мали заобимазак на путу који води ка кући“. ${ }^{44}$ Неки британски мистови су чак наводими Аа ће Броз покушати Аа промени негативни став Египта према БагАадском пакту. Аруги су пак, као италијанска Ansa, сматрали да су посете Етиопији и Египту куртуазног карактера. ${ }^{45}$

Бимо је и реалнијих процена, које су предвиђале Аа ће разговори превасходно тећи у правцу преговора о спровођењу принципа мировубиве коегзистенције, напретку билатералних односа (пре свега економских), питања уједињења арапског света и изградње Асуанске бране. ${ }^{46}$ Посебну пажњу привлаче чланци који прогнозирају Аа Јосип Броз неће одиграти посреАничку року на Блиском истоку. Амерички United Press је у броју за 29. децембар писао Аа „иако је веома могуће Аа ће Насер питати Броза шта мисли о ситуацији

40 Исто.

41 AJ, 837, I-2/5-2, 674.

42 Исто, I-5-6/без броја, Реферат о арапско-израелском спору и односима Египта са Векиком Британијом и САА.

43 AJ, 112-181, Црвени билтен за 27. 12. 1955. Године. Пошто је Израел још током 1954. и 1955. године више пута настојао Аа организује посету југословенског преАседника, израелска штампа се приАружила овој иницијативи. Његова влада је чак 29. децембра израдика нацрт могућег мировног уговора са Арапима у сеАам тачака, са посебним освртом на Египат. Исто, ф. 182, Црвени билтен за 05. 01. 1956. године.

44 AJ, 837, I-2/5-2, 667.

45 АJ, 112-179, Црвени билтен за 08. 12. 1955. године.

46 AJ, 837, I-2/5-2, $661-678$. 
у Палестини, тај разговор неће преАстављати југословенско посреАовање у спору између Израела и арапских земаља“. ${ }^{47}$ Times је крајем децембра објавио текст свог Аописника из БеограАа, који је приметио Аа и пореА опширног писања југословенске штампе о Египту и БАиском истоку, нијеАан оА мистова није поменуо израелско-египатски пробкем. ${ }^{48}$

На Западу је бимо и оАређених политичких кругова који нису желели Аа посета југословенске Аелегације афричким земьама Аâ позитивне резултате, без обзира на то какав епимог имала. Стога се у западној штампи појавьују и инсинуације уперене против комунистичког режима у Београду са цињем Аа компромитују Југославију и њеног мидера у очима пре свега арапског света. Италијански мист Giornale d'Italia објавио је 29. децембра чианак о томе да је Југославији оА стране Совјетског Савеза управо бимо испоручено 35 најновијих борбених авиона типа „МИГ“. ${ }^{49}$ Југословенски АСИП је оценио ову вест као „зму измишьотину“. ${ }^{50}$ Неколико дана касније британски медији су писали о томе како ће се Јосип Броз, убрзо посме посете Египту, због бомести повући из политике. Овај коментар је пропраћен хладним одговором југословенског министарства "да су сви ти гласови без основа и једном речју, смешни“. ${ }^{51}$

За потребе толико очекиваних преговора које је југословенска делегација водика током боравка у Египту, АСИП је израдио неколико припремних студија. Пре свега би требало поменути реферат о БАиском истоку и приручник са политичким, економским, Аруштвеним, социјалним и историјским аспектима египатске Аржаве. ПореА тога, направьен је и приручник са биографијама водећих египатских политичара, а превеАени су и говори Аалса и ИАна поводом ситуације на Блиском истоку. Са поменутим рефератима морали су Аа се упознају сви чланови демегације. Припремни материјал је означен као строго поверьив.

Током боравка Југословена у Египту Ава пута су вођени званични разговори. Броз и Насер су први пут разговарали у Каиру 29. Аецембра, а Аруги пут недеву Аана касније, односно 5. јануара, такође у главном граду Египта.

Првом састанку Авојице Аржавника у палати Кубех присуствовали су са југословенске стране Аржавни секретар иностраних послова Константин Поповић, преАседник Скупштине Србије Петар Стамболић, Јоже Вилфан и амбасадор Марко Никезић. Египат су преАстављали министар иностраних послова МухамеА Фавзи (Fawzi), Аржавни секретар пуковник Али Сабри (Sabri) и египатски амбасадор у Београду Хусеин РужАи (Rushdie). Разговори су отпочели у 10:00.

47 Исто, 669

48 Исто, 668.

49 Исто, 670.

50 АЈ, 112-181, Црвени билтен за 29. 12. 1955. године.

51 Исто, кут. 182, Црвени билтен за 04. 01. 1956. године. 


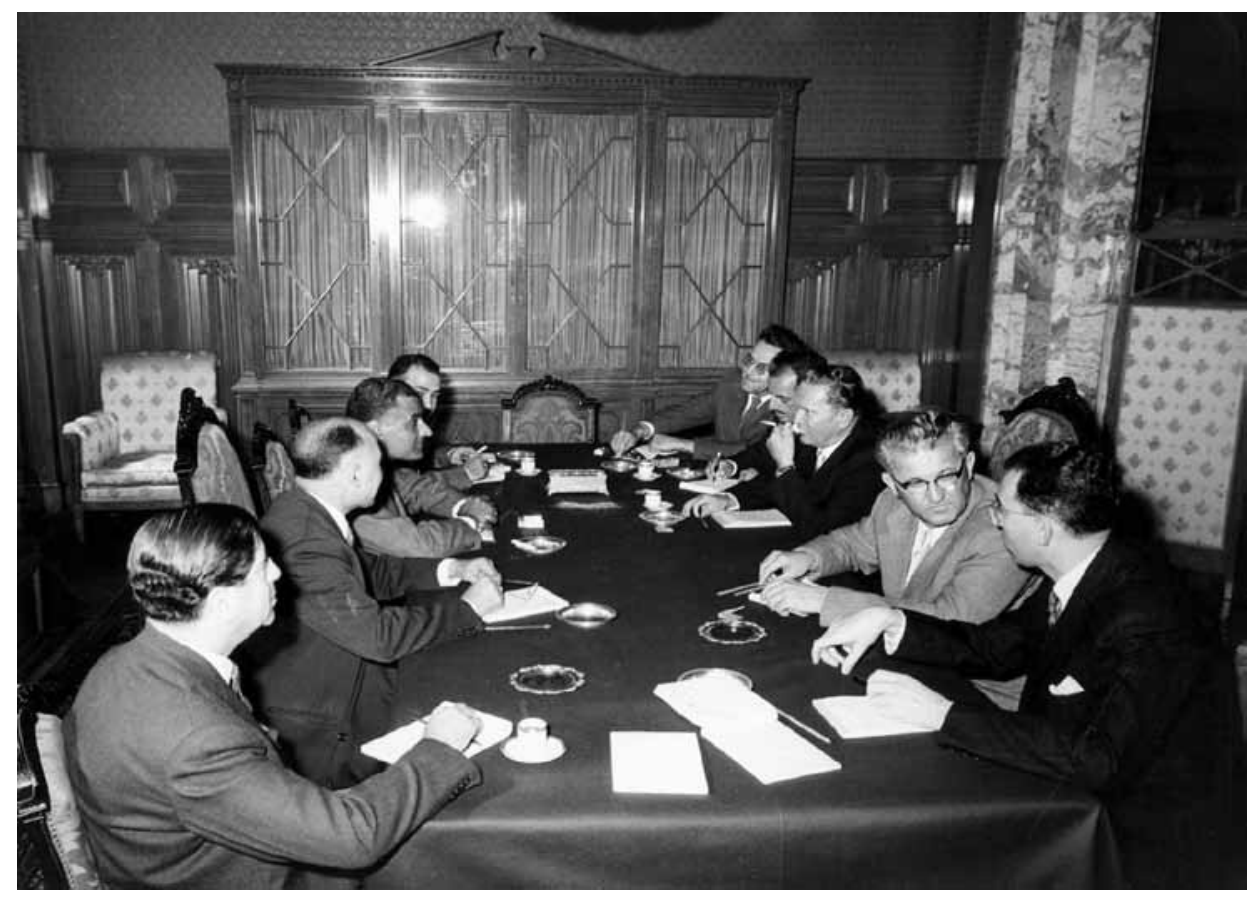

Слика 7. Разіоовори на највишем нивоу 29. 12. 1955. їоgине у йалайи Кубех (Музеј Jyīocıавије)

На Брозово питање о чему би Насер желео Аа разговара, овај је, између осталог, преАложио: оцену опште међународне ситуације, питања Блиског истока, БагАаАског пакта и присуства великих сила у региону, ситуацију у Азији после посете Совјета, оцену опште ситуације у Африци са акцентом на Етиопију, односе са Израелом, ширење активне мирољубиве коегзистенције у свету и питање унапређења југословенско-египатске сарадње. ${ }^{52}$

Југословенски преАсеАник се сложио са оваквим програмом и први узео реч. После краћег реферисања о Женевској конференцији и совјетском присуству у Азији, ${ }^{53}$ он се Аотакао пактова на БАиском истоку. Говорећи о њиховој непотребности и неефикасности, Броз је додао Аа БагАаАски пакт „штети арапским земљама и њиховом јединству више него што је усмерен на оАбрану оА СССР“ ${ }^{54}$ Он је упознао Насера и са мимоилажењима помитика великих сила, појашњавајући како неке оА њих желе економски Аа помогну земье Блиског истока и тако их одвоје оА Совјета, Аок Аруге и Ааље желе Аа спроводе политику „devide et impera“" како би задржале своје позиције. ${ }^{55}$

52 AJ, 837, I-2/5-2, 536.

53 Броз је присуство Совјета у Азији оценио као „позицију више“ уз коментар „Аа је свејеАно са које стране помоћ долази, ако је она без услова и ако је што већа“. Исто, 541.

54 Исто, 538.

55 Исто, 540. 
ПреАсеАник Југославије се потом дотакао питања посредовања између Египта и Израела, на којем је ЗапаА инсистирао. Истакао је следеће: „Светска штампа је писала Аа Һу ја вероватно посредовати између Израека и Египата. Не оспоравам да је било сугетсија оА Аалса Аа посредујем. ОАговорио сам да немамо претензија на посредовање, али Аа ћу изнети шта мислим“". ${ }^{56}$ Управо је то и учинио. Говорећи о арапско-израелским односима, он је остао на ранијим југословенским позицијама да арапске земье морају да се помире са постојањем Израела, јер западне симе неће одустати оА својих позиција по том питању. У том контексту је Аодао Аа, ако не би било „могуће решити га и створити боље односе, оно бар смирити ситуацију“, јер је

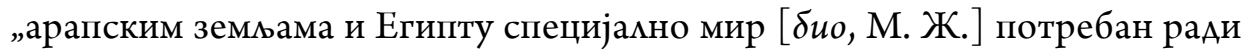
унутрашњег развоја“. 57

Затим се прешио на проблеме колонијализма. Ту је Броз инсистирао на побољшању односа између три независне афричке земье (Египат, Етиопија и СуАан) како би се ојачама њихова позиција у односу на велике симе. Као пример својих тврАњи Броз је навео Балкански пакт и сараАњу између Југославије, Грчке и Турске. У наставку он се Аотакао блоковског неангажовања, наводећи Египћане како да искористе повећано присуство СССР у региону. Насеру је поручио Аа је у тренутној констелацији снага могућно извући помоћ оА оба блока, јер свака велика сима „мисли Аа ако та земьа није коА ње, нека бар буде ван блокова, а не код оног Аругог“. ${ }^{58}$ Присуство Совјета Броз је окарактерисао као „јеАну позицију више и то су азијске земье требало да искористе“. ${ }^{59}$ Поучен, међутим, сопственим негативним искуством, Броз је саветовао Насеру дозу опреза при односима са Москвом („Тешко је сазнати какве су праве намере Руса. Све те осмехе треба примити 'cum grano salis'. Ми имамо моше искуство. Наду нам дају сазнање Аа су нови курс у Совјетском Савезу почели нови ьуди и то не без опозициј““). ${ }^{60}$

Током свог измагања египатски мидер Насер се фокусирао на БагАаАски пакт и проблем арапско-израелског спора. Пакт је оценио као дестабилизујући чинилац на Блиском истоку, а његовог промотера Турску као западни фактор који би требало Аа уради „оно што сам [3aйag, М. Ж.] није могао Аа учини““. ${ }^{61}$ Спор са Израелом Насер је упоредио са „зачараним кругом“. Ако би Египат покренуо мировну иницијативу, САА би то искористиме Аа га представе као нелојалног према другим арапским земьама, Аок су са Аруге стране саме користиле „израелски проблем како би убедике Арапе

56 Исто, 541.

57 Исто, 541.

58 Исто, 544.

59 Исто, 541.

60 Исто, 545.

61 Исто, 548. 
Аа неће моћи сами да се бране оА израелске агресије“. ${ }^{62}$ Насер је тренутну ситуацију описао као нестабилну и чак највио саговорнику могући оружани сукоб у блиској будућности. Закьучио је Аа је најбоље Аа се проблем са Израелом реши у оквирима ОУН. ${ }^{63}$ После ових речи више није говорио о израелско-арапском конфмикту.

Прешао је затим на Африку. Према Насеровом мишьењу, она је бика послеАњи стожер колонијалне политике и стога су је Велика Британија и Француска браниме оА било чијег утицаја. „Аанас све колонијалне силе у Африци раде против Египта. Ми не можемо слати нигде никог, нпр. у Кенију, Уганду и Аруге крајеве. Свуда према нама поступају моше. Тако је и у Северној Африци гАе не можемо Аа имамо никаквог преАставника. У Аибији влада је напустила сарадњу са Египтом, јер је добила наредбу да сарађује са Турском и Ираком“, Аодао је Насер у наставку састанка. ${ }^{64}$ О Етиопији је говорио негативно. Иако је истакао Аа Египат мора са њом имати добре оАносе, он је прокоментарисао Аа му се чини како „Абисинија ради са САА и Великом Британијом против јединства Судана и Египта“. ${ }^{65}$ На крају свог измагања египатски преАсеАник се заложио за побољшање биматералних оАноса са Југославијом, поготово на економском плану.

Потом је и Броз говорио о Етиопији, као што је обећао цару Хаиле Семасију (Selassie). Поручио је Насеру Аа Етиопьани жеме Аа Аају муслиманима већа права и да сматрају да верски проблеми не би требало Аа буду кочница развоју добросусеАских оАноса. Броз је притом, оправАавајући приближеност Етиопије Западу (што је највише сметало Насеру), додао Аа није „видео никакве велике размике у ставу према комонијализму“ између етиопског цара и египатског преАсеАника. Аржање Етиопьана он је оценио као неизбежно, с обзиром на то Аа је Аревна царевина и економски и војно била слабија оА Египта. ${ }^{66}$ Аидер југословенских комуниста је исказао спремност Аа посредовањем помогне овим државама у поправљању односа.

Затим се још једном дотакао питања арапско-израелског спора. Желео је Аа сазна Аа ми је могуће постепено, односно одвојено решити неке проблеме, на пример, питање избеглица. Такође, интересовао се како Египат гледа на проблем разграничења са Израелом. Насер је одговорио да сматра Аа је немогуће посебно решити проблем избеглица и Аа ће његова земьа тежити територијалној граници са ЈорАаном. Тиме је југословенском преАсеАнику још једном ставио до знања Аа није спреман Аа прихвати никакво посредовање у спору са Јеврејима. Састанак је завршен у 14:00.

62 Исто, 549.

63 Исто, 550.

64 Исто, 552.

65 Исто, 552.

66 Исто, 553. 
Петог јануара 1956. године уследили су нови разговори Аве Аемегације, овога пута у јеАном цуксузном одмаралишту неАалеко оА Каира. Преговорима су присуствовали само Јосип Броз и Јоже Вилфан са југословенске, односно Насер и потпреАсеАник Салем (Salem) са египатске стране.

Јосип Броз је отворио Аругу рунду разговара охрабрујући Египат Аа остане на минији политике блоковске неангажованости и сматрајући Аа ће успети у настојању Аа води независну политику. Притом је навео пример Југославије коју је ЗапаА наводно више волео као несврстану „него у супротном 6 коку“, па је због тога био „спреман и на помоћ без услова“. ${ }^{67}$ Подршка искусног Аржавника какав је не-

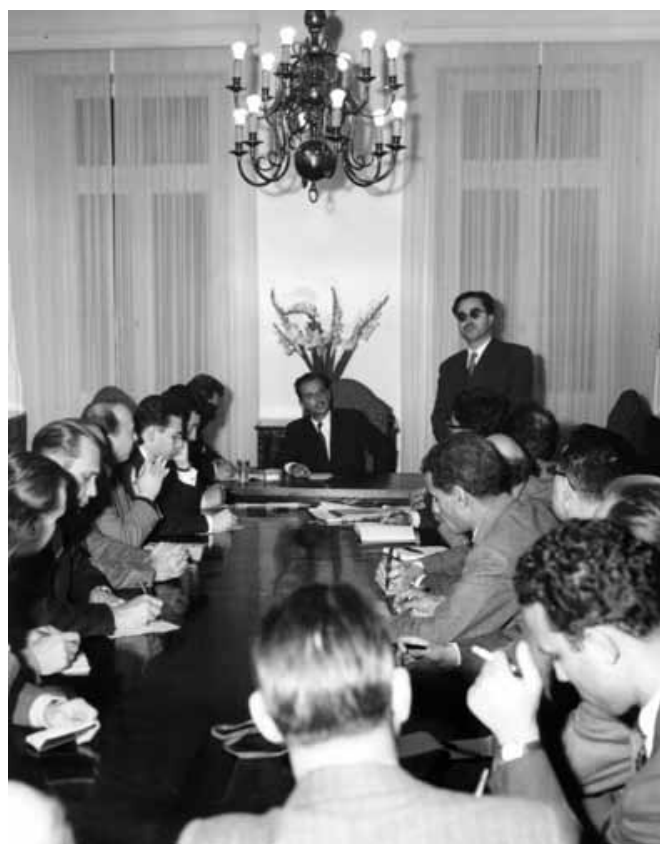

Слика 8. Констианйин Пойовић на конференцији за шитамӣу 5. јануара 1956. їодине (Музеј Jyїославије) сумњиво био Јосип Броз, свакако је охрабрияа египатског мидера Аа остане на зацртаном спољнополитичком курсу. Насер се овога пута посебно распитивао за југословенско-совјетске односе Ао 1955. године.$^{68}$ Остатак састанка је потрошен на усаглашавање више билатералних споразума и коминикеа. ${ }^{69}$

У заједничкој изјави која је изАата у форми декларације, преовлађивао је став подршке антиколонијалним покретима и новонасталим државама, блоковској неангаожованости и принципима активне мировубиве коегзистенције. Авојица Аидера су потврдили обострану приврженост политици несврстаности и осудили помитику војних бцокова и пактова под образможењем Аа она „неизбежно повлачи за собом самоубилачку трку у наоружању, изазива неразумевање међу народима и повећава затегнутост у свету“. ${ }^{70}$ Притом су поздрављене одлуке Бандуншке конференције из априяа 1955. године. На крају су исказане жеље за јачањем југословенско-египатских односа на свим пољима сарадње.

Ради читања коминикеа заказана је 5. јануара 1956. године конференција за штампу, којој су присуствовали и страни дописници. На њихова питања

67 Исто, 583.

68 Исто, 585-586.

69 Исто, 584.

70 Исто, 600. 
оАговарао је Коснатнтин Поповић. На оно најважније, Аа ми ће доћи до југословенског посредовања у арапско-израелском сукобу, Поповић је кратко одговорио Аа „у погледу Израела није било ни посредовања, а још мање интервенције маршала Тита“. ${ }^{71}$ Ове наводе је потврдио и Броз у интервјуу Борби три Аана касније, 8. јануара (Broz 1959: 365).

Притом је напао БагАаАски пакт и Аао подршку египатској антиколонијалној и, пре свега, антибританској политици. То је учинио и током говора у Пуки 10. јануара преА 60.000 ьуди. ${ }^{72}$ Критика колонијализма је такође била присутна у излагањима југословенског преАсеАника. „Египту је у томе потребна помоћ извана, јер он то није кадар сам да постигне. Њему је тешко самом и, уколико би сам био себи препуштен, требало би му много времена. Ми смо се убедими, како у Египту, тако и у Етиопији, да тим народима треба Аати подршку извана, Аа ту треба Аа Аође Ао пуног изражаја помоћ неразвијеним земьама“, изјавио је између осталог Броз у Пули (Broz 1959: 381). У наставку је АоАао и Аа „Египат неће рат“" и Аа преко Југославије поручује „Аа жели живети у миру, Аа жели очувати своју независност и да је чврсто ријешен Аа се више никада не врати оно што је бимо, то јест страна Аоминација“" (Broz 1959: 381 ).

По повратку из Египта Јосип Броз се запутио у БеограА. Током пута говорио је у неколико градова - Бубњани, Новском, Славонском Броду, Винковцима и Сремској Митровици. Сва обраћања јавности била су слична измагању у Пули. У Бубњани је 11. јануара, на пример, изјавио Аа „би већ требало Аа ьуди који још имају стара схватања о међународним односима напусте та схватања и прилагоде се новој ситуацији, па Аа воде рачуна о томе шта мисле и народи малих земаља“" (Broz 1959: 386).

Митинг Аобродошлице у Београду, на којем је присуствовало око 200.000 ьуди, ${ }^{73}$ преАстављао је врхунац критике западне политике на БАиском истоку. Поводом питања БагАадског пакта Броз је изнео мишьење Аа ,је баш тај пакт јеАна ствар која ьуде тамо јако забрињава, и Аа је тачна она константација, о којој сам већ говорио, Аа је то елеменат разједињења а не ујеАињења среАњоисточних земаља“" (Broz 1959: 395-396). Броз се осврнуо и на питања наоружавања Египта совјетским војним материјалом, Аругу болну тачку за ЗапаА, коју је оправдао речима: „Ја сам за то Аа сваки народ има право Аа се наоружава, а особито они народи, који немају наоружања, ради своје самоодбране... Египат се не наоружава ради неког реванша, они отворено кажу да желе сачувати мир, али сматрају да имају право Аа набаве оружје тамо гдје могу“ (Broz 1959: 396-397).

Чврст став југословенске Аипломатије у критици БагАадског пакта поклопио се са извесним променама на Блиском истоку које су ишле у корист египатских интереса. Аесетог јануара у Јордану је пама пробританска вцаАа,

71 Исто, 648.

72 АJ, 112-182, Црвени билтен за 10. 01. 1956. године.

73 АJ, 112-182, Црвени билтен за 13. 01. 1956. године. 


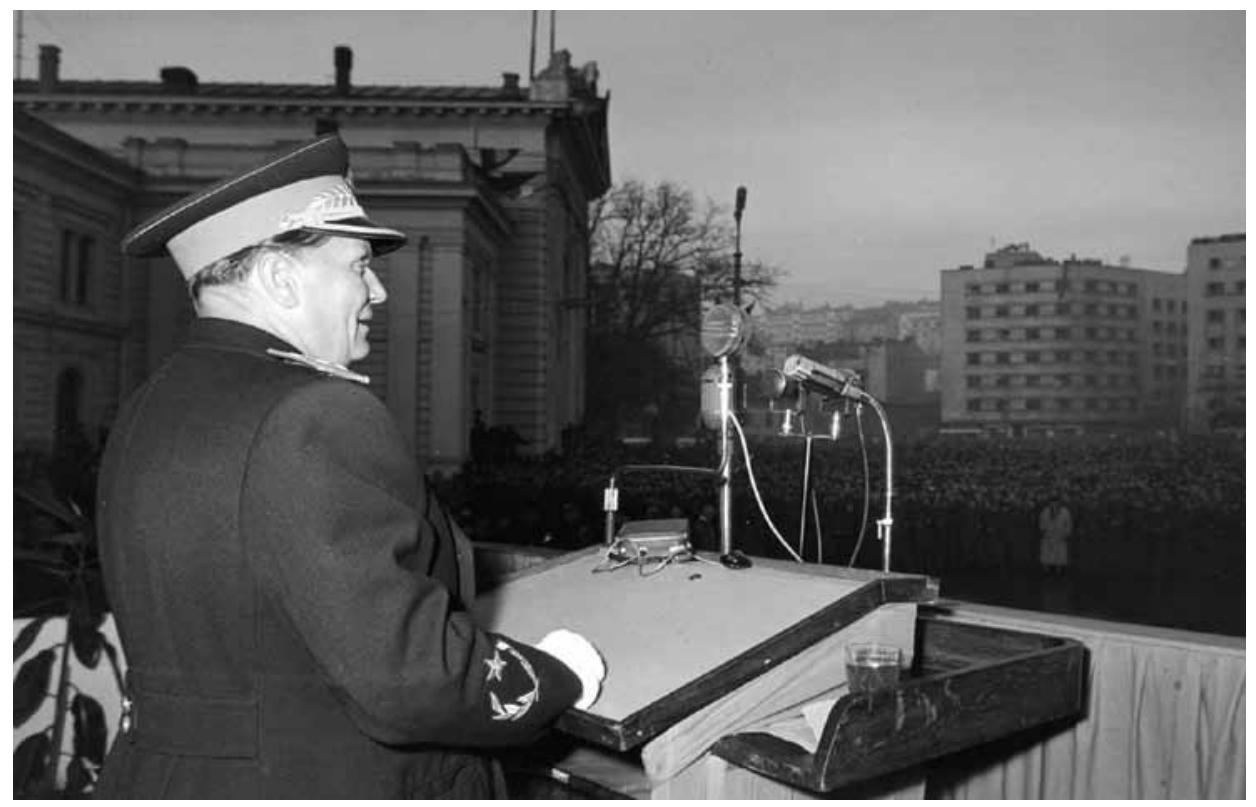

Слика 9. Говор Јосийа Броза на мит̄ині̄y у Беоїраgy

(Музеј Jуїсславије)

Аок је нова вцаст одиучияа да не ступа у војне савезе, односно да заузме неутралан став. ${ }^{74}$ Аа би подржале јорданску влаАу у својој намери и чвршће је везале за себе, Египат, Сирија и Саудијска Арабија су израдиме план десетогодишње економске помоћи овој земьи у укупној висини оА 280 микиона $\$ .^{75}$ Сирија је притом одбила кредит Светске банке уз образложење Аа штети интересима земье. ${ }^{76}$ Египат је после три године Аобио нови Устав, који је учврстио Насерову вмаст у Египту.

Позицију запаАних сима на Блиском истоку Аодатно су отежали поступци Израела. У новом нападу на Сирију у подручју Галикејског језера, среАином јануара 1956. године ${ }^{77}$ погинуло је 56 сиријских и шест израе ских војника. ${ }^{78}$ Аибан, који је до тада био потпуно под контромом ЗапаАа, скмапа оАбрамбени савез са Сиријом и удаљава се оА БагАаАског пакта. ${ }^{79}$ Југославија је убрзо поднела резокуцију ОУН у којој је захтевала Аа се поступци Израека најригорозније санкционишу, стајући на страну арапског света. ${ }^{80}$

74 АJ, 112-182, Црвени билтен за 10. 01. 1956. године.

75 Исто.

76 Исто, кут. 183, Црвени билтен за 12.01. 1956. године.

77 Израел је извршио и јеАан мањи напаА на Египат у подручју Газе 31. Аецембра 1955. године, још у време Брозовог боравка у Египту, приликом којег је погинуо јеАан египатски војник. Исто, кут. 181, Црвени билтен за 31. 12. 1955. године.

78 Исто, Црвени билтен за 19. 01. 1956. године.

79 Исто, Црвени билтен за 14. 01. 1956. године.

80 Исто, Црвени билтен за 11. 01. 1956. године. 


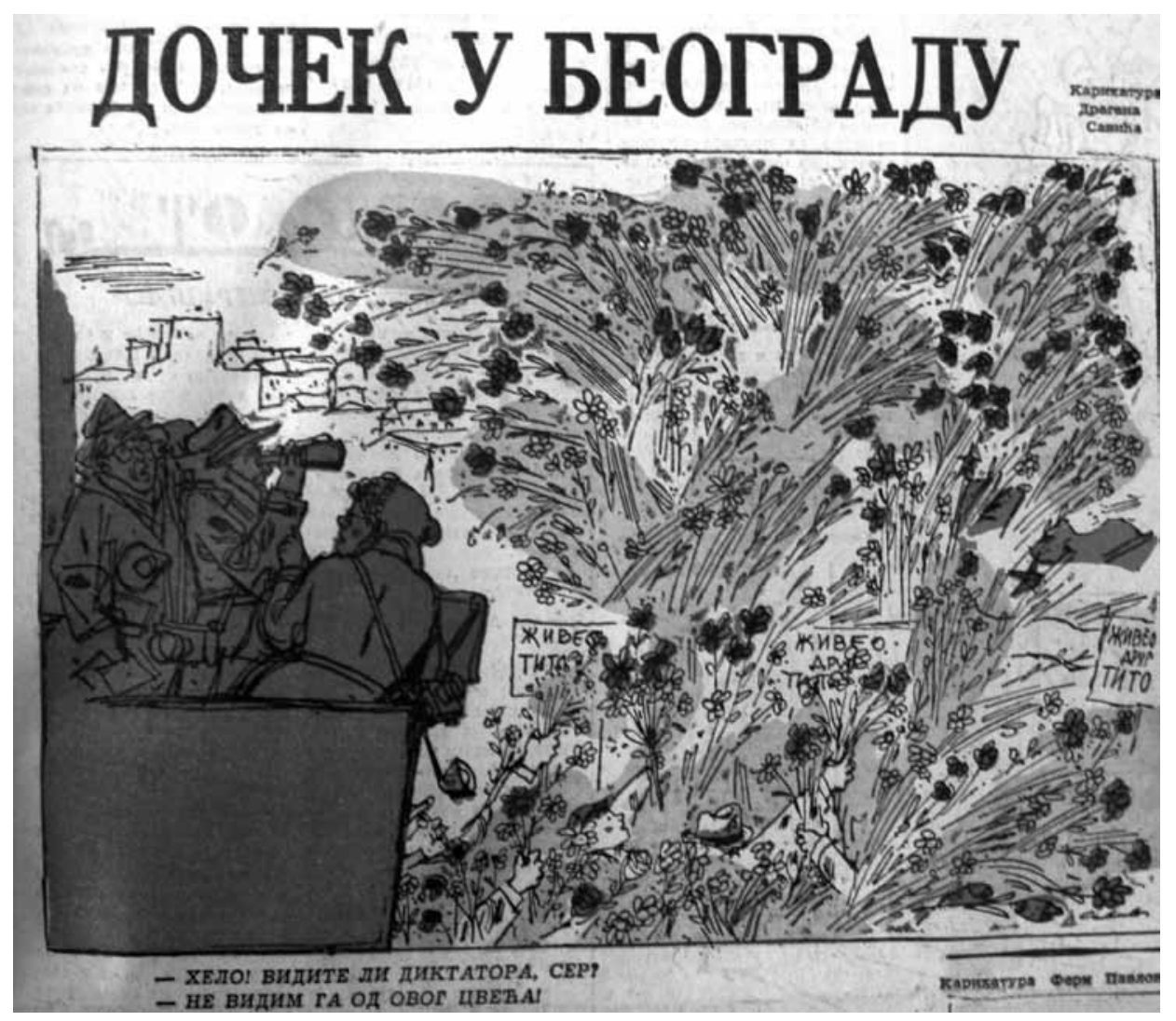

Слика 10. Карикайура из часойиса Јеж, 1956. іолина

За само пет Аана југословенски преАсеАник је својим изјавама узАрмао везе са Западом, поготово односе са Аондоном. Неиспуњење Аатих гаранција, подршка Аањем египатском приближавању СССР-у и Брозова критика БагАаАског пакта, проузроковали су велико незадовофство. ИАн је чак почео Аа трпи критике оА стране партијских колега због промашаја у блискоисточној политици, односно због афере око продаје британског половног наоружања Египту ${ }^{81}$ и неуспеха Брозове мисије. ${ }^{82} \mathrm{C}$ Аруге стране, САА су негодовале јер је југословенска дипломатија хвалила египатску куповину оружја и чак саветовала Насеру да настави сарадњу са СССР-ом по питању изграАње Асуанске бране, што је значимо и Аањи продор совјетског утиција у овај регион. И Француска се придружика критици.

Западна штампа је Брозове наступе углавном ставњала у контекст совјетске посете Азији у децембру 1955. године. Британски мист News Chronicle у свом броју за 6. јануар 1956. године критикује мидера југословенских комуниста

81 Исто, Црвени билтен за 01. 01. 1956. године.

82 Исто, Црвени билтен за 06. 01. 1956. године. 


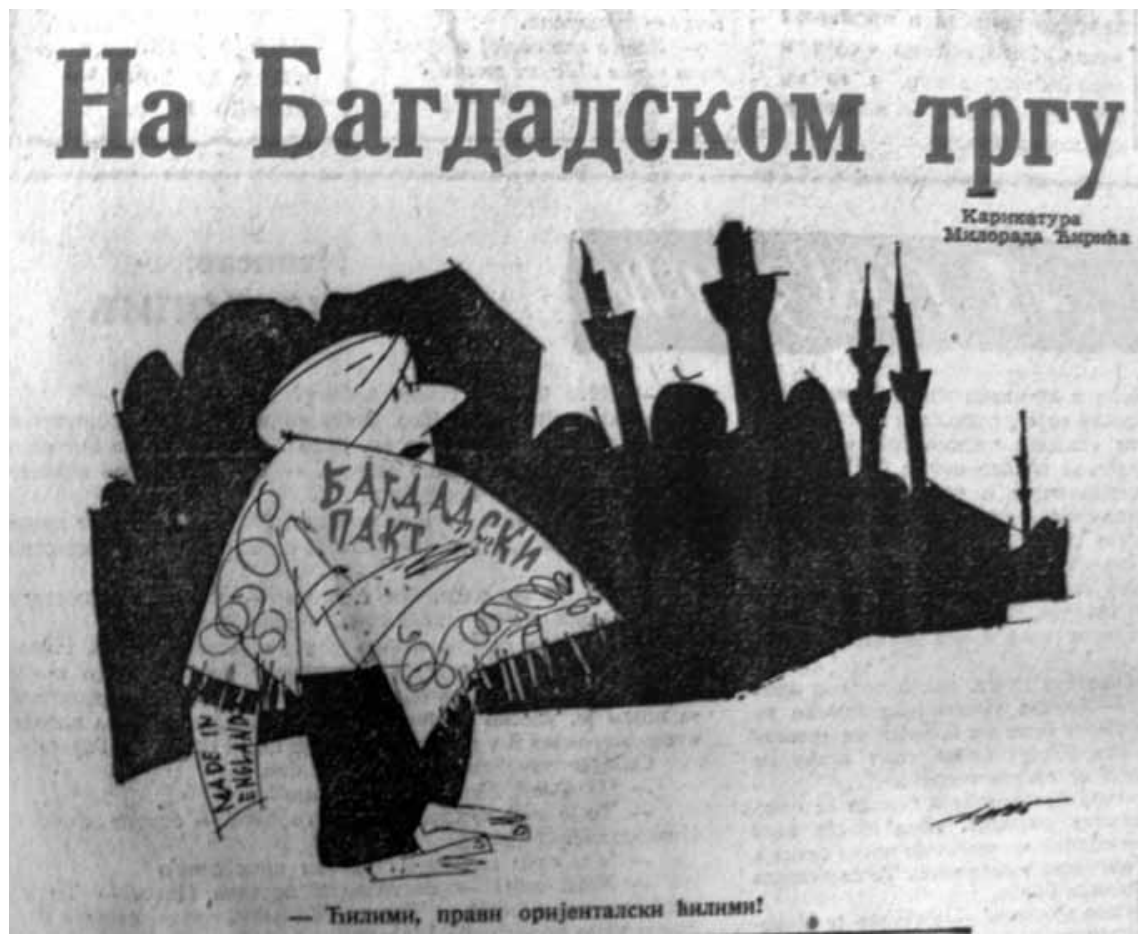

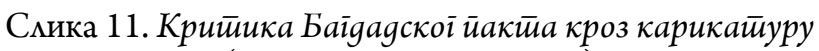

(Јеж, јануар 1956. іолине)

због „превејане“ политике и каже Аа је „египатски преАсеАник Насер стекао новог савезника против БагАаАског пакта чији је покровитељ ЗапаА Југославију“. ${ }^{83}$ Manchester Guardian је мало блажи и износи став Аа југословенска дипломатија преувеличава чињенице на којима темеьи свој негативни став према поменутом пакту. ${ }^{84}$ New York Times пак отворено напада Југославију да се налази да минији Москве. У јеАном оА чланака за 9. јануар каже се следеће: „ОАлука маршала Тита Аа се без стварних размога придружи противницима БагАадског пакта, ствара више тешкоћа него икаА, пријатељима Југославије, који желе Аа бране појам неутралне Југославије која се не изјашњава ни за Исток, ни за ЗапаА и настоји Аа скужи само интересима мира." ${ }^{85}$ У наставку поменутог чланка Броз је критикован што замера Аржавама које се због страха оА совјетског утицаја укьучују у БагАаАски пакт, каАа је на својој кожи осетио шта значи опасност оА СССР. Аутор чианка повезује наступе југословенског Аржавног врха са немирима у Јордану, које према његовом мишьењу воде комунисти уз благослов Кремьа и БеограАа.

83 Исто, кут. 182, Црвени билтен за 06. 01. 1956. године.

84 Исто, кут. 183, Црвени билтен за 17. 01. 1956. године.

85 Исто, кут. 182, Црвени билтен за 09. 01. 1956. године.

86 Исто, кут. 183, Црвени билтен за 12.01. 1956. године. 


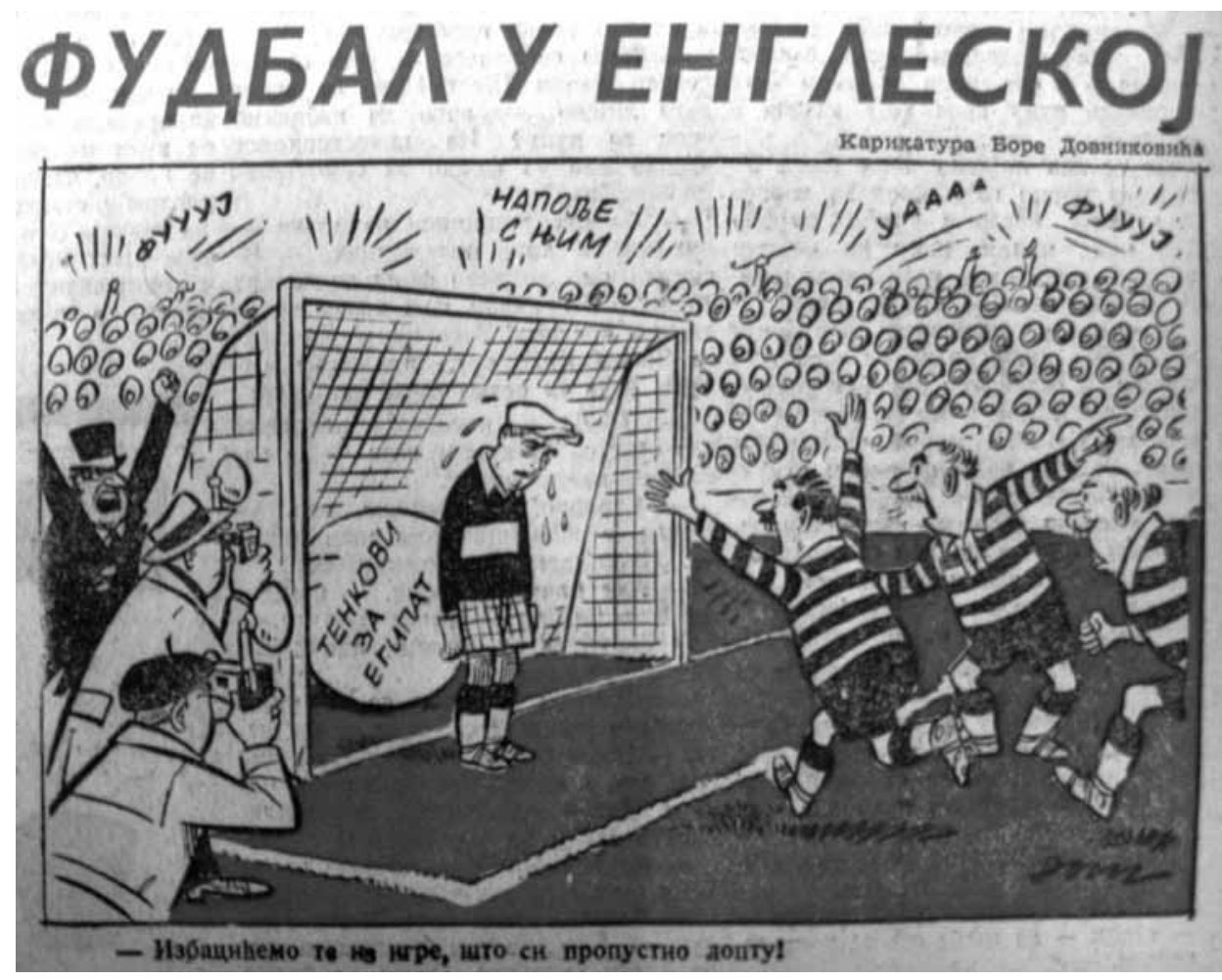

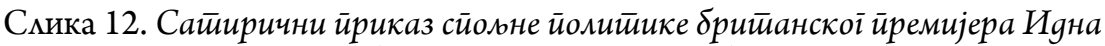
(Јеж, јануар 1956. іолине)

Коментаришући Брозов говор у Београду оА 12. јануара, The Washington Post га отворено критикује Аа је кратковиА политичар који наступа у складу са совјтеским ставовима изнетим током Хрушчовљевог боравка у Азији. У том контексту мист се питао „може ми маршал Тито бити тако слеп Аа не виАи нову страну доминације и опасности по независност Египта, која је произашла из присуства комунистичког оружја у Египту и очевиАних напора проширења совјетског утицаја у тој земьи? “87 Париски Combat је изнео мишьење Аа, иако ће Југословени покушати Аа сачувају добре односе са Вемиком Британијом, мораће Аа сносе последице оштрог напада на БагАаАски пакт. ${ }^{88}$ Италијански Il Piccolo је проницьиво приметио Аа је Броз све мање „причао о мировубивој коегзистенцији на Блиском истоку, а све више непристрасно критиковао Багдадски пакт“ ${ }^{89}$ Аист тадашње италијанске владе Il Messaggero се придружио горе изнетој осуди упозоравајући да ће Југославија морати да сноси последице. ${ }^{90}$

87 Исто, Црвени билтен за 16. 01. 1956. године.

88 Исто.

89 Исто, кут. 181, Црвени билтен за 08. 01. 1956. године.

90 Исто, кут. 183, Црвени билтен за 16. 01. 1956. године. 


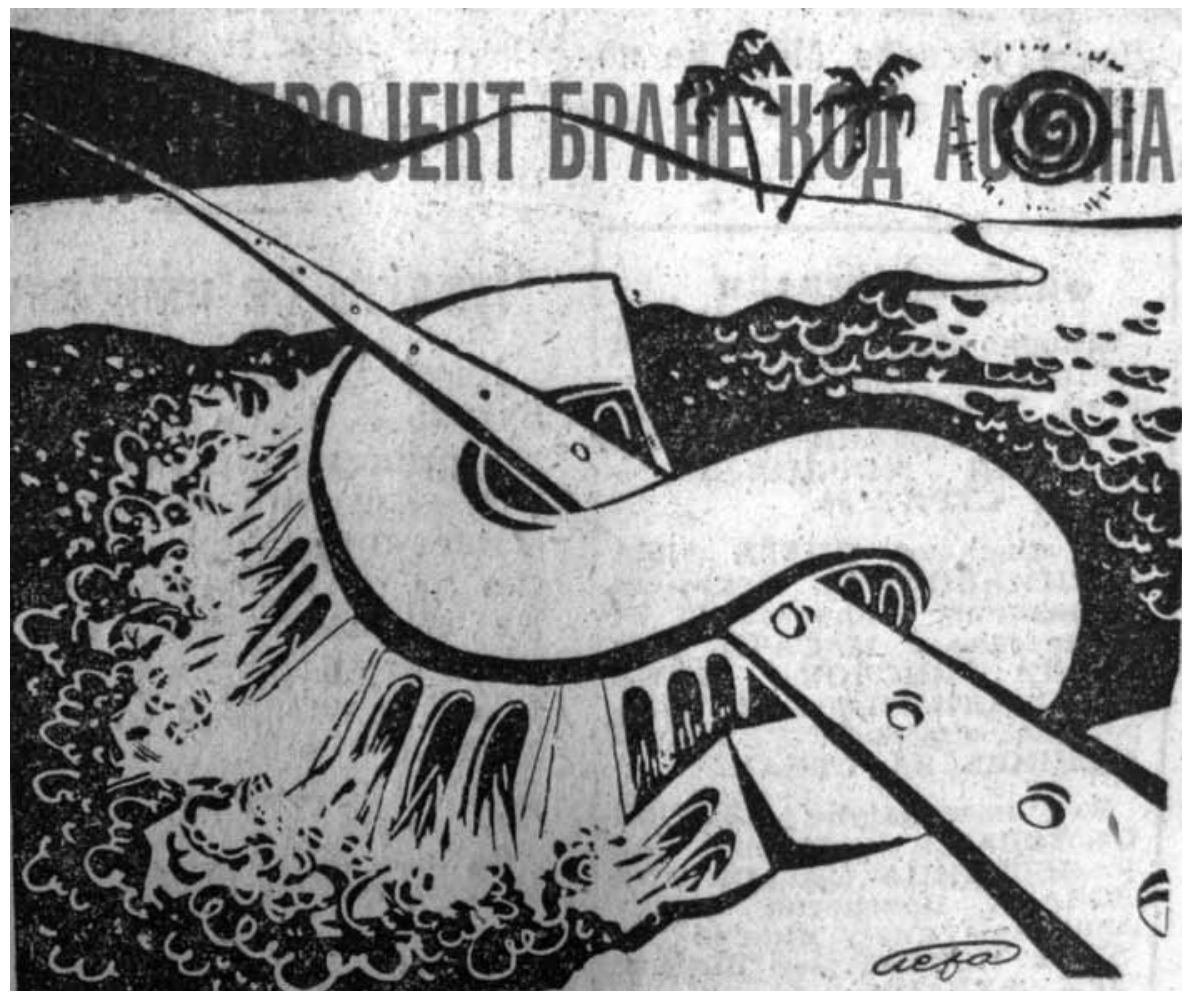

Слика 13. Сайирични йриказ изі̄pagње бране коg Асуана у Еїиӣ̄̄u (Јеж, јануар 1956. іолине)

ПореА штампе, западне симе су извршияе пртисак на југословенску влаАу и Аипломатским путем. Већ 9. јануара Ентони ИАн је наложио британском амбасадору у Београду Франку Роберсту (Roberts) Аа интервенише коА ЕАварда КарАева не би ми Броз престао са нападима против његове вмаАе. ИАн је свој протест образмагао чињеницом да се на тај начин подржавају египатске намере Аа мобимишу арапски свет против Израела и поткопава британски положај на Блиском истоку (Batović 2008: 365). Робертс је покушао Аа умири свог наАређеног подсећајући га Аа је Броз и раније изнео своје критике према пакту и Аа у његовим скорашњим изјавама нема ничега новог (Petrović 2007: 117). Он је ипак 14. јануара уможио протест коА секретара иностраних послова Константина Поповића. Том приликом је нагласио Аа су Брозови ставови у супротности са гаранцијама које је изнео Кардељ у новембру 1955. године („сегмент наше блискоисточне политике извргнут је јавној осуди без икаквог упозорења. Све што је британска и светска јавност сазнала о Титовим разговорима у Каиру био је напаА на нас и на Аруге чманице БагАадског пакта“) (Batović 2008: 365).

Увидевши Аа су односи са Великом Британијом доведени у питање, Поповић, који иначе није одобравао превелику и отворену поАршку 
Египту, ${ }^{91}$ морао је Аа ублажи југословенски став. Он је навео да се ради о изАвојеном екцесу и АоАао како Брозови иступи неће утицати на југословенско-британске односе у целини. Према Робертсовом утиску, он је „пружио извињење у мери у којој то може Аиктаторов министар иностраних послова, најеђен због Аиктаторових речи“" (Petrović 2007: 124). Поповићев и Робертсов оптимизам није могао Аа умири кавину незадовољства које су на ЗапаАу покренули Брозови говори. ОАговор ИАна био је веома хлаАан: „НаАам се Аа ни Робертс, нити ико Аруги неће прихватити ово од Тита. У сваком случају, наш је мото, нема више пара за њега“. За британским амбасадором је Аошао турски, а за њим амерички. И преА њима је Поповић ублажавао ставове комунистичког мидера изјавьујући „Аа Југославија нема намеру бити активна на овом пољу, нити има немеру водити битку против БагАаАског пакта“" (Batović 2008: 365-366). У наредним данима је због тога престала Брозова отворена критика британске блискоисточне политике. Званични став Југославије је, међутим, остао исти по већини питања о којима је њена Аипломатија говорила током посете Египту и непосреАно после ње, што ће јасно показати године које су долазиле.

Боравак југословенске Аелегације у Египту преАстављао је организационо захтеван подухват. То нам говоре како проблеми на релацији БеограА ААис Абеба - Каиро око утврђивања Аатума, тако и опсежан раА на текућим питањима (одређивање одела, униформа, музике, хотела, јеловника, доласка Јованке Броз, вакцина, покмона, одликовања, цокација за посећивање итА).

Јосип Броз је искористио прилику аа током разговара са преАставницима Египта позове Насера Аа се измири са израелским сусеАом. Притом му је ставио до знања Аа тај преАлог не потиче оА њега већ оА вмаАе САА (то је Аиректно учинио Ава пута). Насер је такође у Ава наврата суптилно оАбио југословенског мидера (проблем са Израелом „зачарани круг“, скорији оружани сукоб са овом земьом), ами се приАружио његовој критици Багдадског пакта.

Видевши Аа Египћани не желе Југославију у улози посредника између њих и Израела, Јосип Броз је заузео позицију јавне одбране њихових интереса, као будућих активних савезника на међународном плану (пре свега по питању активне мирољубиве коегзистенције). То се види у: поАршци политици антиколонијализма и блоковске несврстаности у коминикеу; јавном порицању аа је Израел уопште помињан током билатералних разговора; Брозовим критикама БагАаАског пакта у Борби и током говора у Пули, Һубьани и БеограАу; подршци Египту у ОУН после нове ескамације сукоба

91 Константин Поповић је у једном интервјуу 1989. године изјавио: „Сматрао сам, на пример, Аа смо неким нашим партнерима међу несврстаним, посебно арапским земьама, правили оАвећ.векике уступке на рачун истинске несврстане политике“ (Ненадовић 1989: 125). 
на Блиском истоку итА. У томе се ишло Ао крајњих граница, с обзиром на то Аа су критике које су из Београда стизале на рачун Запада престале тек после протеста неколико страних амбасадора југословенском АСИП.

\section{ИЗВОРИ}

Архив Југославије, ТАНЈУГ (фонА 110), Кабинет преАсеАника републике (фонА 837) Музеј Југославије, збирка фотографија

\section{АИТЕРАТУРА}

Batović 2008: Ante Batović. „Britansko-jugoslovenski odnosi od Bagdadskog pakta do Suecke krize“. Spoljna politika Jugoslavije 1950-1961. Beograd: Institut za noviju istoriju Srbije. Broz 1959: Josip Broz Tito. Govori i članci 1941-1957. X. Zagreb: Naprijed.

Ненадовић 1989: Александар Ненадовић. Разіовори са Кочом. Загреб: Књижевна реч.

Petrović 2007: Vladimir Petrović. Jugoslavija stupa na Bliski istok. Stvaranje jugoslovenske bliskoistočne politike 1946-1956. Beograd: Institut za savremenu istoriju. 


\section{Milutin D. ŽIVKOVIĆ}

\section{VISIT OF YUGOSLAV PRESIDENT JOSIP BROZ TO EGYPT}

(28. 12. $1955-06.01 .1956)$

\section{SUMMARY}

The trip of the Yugoslav delegation to Egypt took place at the end of December 1955. It was a demanding diplomatic campaign. In the course of ten-day stay in the country situated on the Nile River, Josip Broz Tito had several conversations with Gamal Nasser. He used the occasion to present Gamal Nasser with the foreign affairs platform of peaceful coexistence that was created by Yugoslavia. In compliance with the wishes of the West, his intention also was to propose to Nasser a peaceful solution of the problems with Israel. Egyptian president, however, rejected this proposal. Therefore, Yugoslav diplomacy supported Egypt and by confronting the interests of the West which threatened this African country, routed its own path at the international scene divided into blocks.

Key words: Yugoslavia, Egypt, Josip Broz, Gamal Abel Nasser, visit, West, Great Britain, Ethiopia, delegation, president.

РаА је предат 3. октобра 2018. године, а након мишьења рецензената, одлуком оАговорног уредника „Баштине“ одобрен за штампу. 